\title{
ESTIMATE OF PARLATORIA ZIZIPHI (HEMIPTERA: DIASPIDIDAE) POPULATIONS USING RCP SCENATIOS
}

\author{
ABD-RABOU, S. ${ }^{1}$ and A. A. FARAG. ${ }^{2}$ \\ 1. Plant Protection Research Institute, ARC, Dokki, Giza, Egypt \\ 2. Central Laboratory for Agriculture Climate, ARC, Dokki, Giza, Egypt
}

(Manuscript received 1 July 2014)

\begin{abstract}
This study aimed to predict the populations of the black scale insect, Parlatoria ziziphi (Lucas) (Hemiptera: Diaspididae), a common pest of citrus in Egypt, during period (2041 - 2070) and (2071-2100) compared with the pest populations of 2000, 2010 and 2012 years. Study was conducted in a citrus orchard at Ismailia District, while Ismailia weather station was used for collecting climate data (maximum and minimum air temperatures) for 2000s, 2010s and 2012s. Climate change data was conducted using climascope tool to extract the projection changes in air temperature under two RCP scenarios (RCP 4.5 and RCP 8.5). HadCM3 climate model was the base model under the two scenarios. Obtained data showed a relationship between mean temperature and nymph numbers with a good fit and a co-efficient of determination of $\mathrm{R}^{2}=0.974,0.988,0.958$ for 2000,2010 and 2012 years, respectively. Also, the relationship between mean temperature and adult numbers gave a good fit to the data with a co-efficient of determination of $\mathrm{R}^{2}=0.965,0.992$ and 0.991 for 2000, 2010 and 2012 years, respectively. The estimated nymph and adult numbers for $P$. ziziphi under the two different climate change Scenario (RCP 4.5 and RCP 8.5) were also studied. The results indicated that the average yearly increase in nymph numbers for period (2071-2100) and period (2041-2070) under RCP 8.5 were $55.3 \%$ and $17.5 \%$, respectively. While under RCP 4.5 were $30.9 \%$ and $12.7 \%$, respectively . It is concluded that a directly proportional was found between temperature and the Predicted population of $P$. ziziphi. which could provide a valuable tool in monitoring, managing and controlling pests spread now in the coming future .

keywords :- black scale, climate change, RCP Scenario, citrus orchard.
\end{abstract}

\section{INTRODUCTION}

The black parlatoria scale, Parlatoria ziziphi (Lucas) (Hemiptera: Diaspididae) is an important pest of citrus in Egypy and many other countries worldwide. It attacks leaves, branches and fruits of citrus trees. The Symptoms of damage include black, subrectangular scales present on shoots, foliage and fruit, but especially on upper leaf surfaces. Depletion of plant sap leads to reduced host vigour, and the foliage and fruit may be discoloured with yellow streaking and spotting due to saliva toxicity (Cole and Abd-Rabou, 1998 and Hassan et. al., 2012). Heavy infestations of citrus cause 
premature senescence and leaf drop, reducing productivity. In the UK and USA, P.ziziphi is often intercepted on imported citrus produce. Immature and adult female $P$. ziziphi are readily carried on plants and plant produce and may be injurious when introduced to new geographical areas without natural enemies (CABI (2007). Injudicious spraying of chemical pesticides can reduce natural enemy populations, allowing P. ziziphi to proliferate (Ulenberg, 2012). In Egypt This pest distributed in six governorates, these are Alexandria , Beheira, Cairo, Fayoum, Giza and Sharquiya (Ghabbour \& Mohammad, 1996 and Coll \& Abd-Rabou, 1998).

El Bolok et. al., (1985) studied the seasonal variation in the population of $P$. ziziphi on sour orange leaves at Giza region during 1982 and 1983. The insect had two peaks of activity per year in April and October. Sweilem et. al., (1985) studied the biology of $P$. ziziphi on sour orange trees in Egypt under field and laboratory conditions. They mentioned that the scale had 2 generations a year. Salama et. al., (1985) reported that $P$. ziziphi on grape fruit in Egypt had two annual peaks of abundance in Sept. and May and there were 3 generations a year in Sept.- Oct., Mar.Apr. and Jun.-Jul. Serag,(1997) reported that P. ziziphi had 2-3 annual generations begin in Jun., Oct. and Apr. to May. Helmy (2000) stated three generations of $P$. ziziphi a year on four citrus varieties (i.e. mandarin, baladi orange, grape fruit, and trifoliate orange trees). Peaks occurred in Apr., Aug. and Oct.

Fifth Assessment Report (AR5) uses four Representative Concentration Pathway (RCP) scenarios with widely differing emissions pathways, reflecting differing levels of ambition in tackling climate change. The lowest, RCP2.6 is a very strong mitigation scenario, with CO2 levels peaking by 2050 at 443ppmv. RCP4.5 has a continuing rise in $\mathrm{CO} 2$ concentrations to the end of the century, when they reach 538ppmv. In RCP6.0, CO2 concentrations rise more rapidly, reaching 670ppmv by 2100 year . RCP8.5 continues current rapidly increasing $\mathrm{CO} 2$ emission trends with concentration reaching 936ppmv by 2100 (IPCC, 2013).

According to some proposals, the predicted increase in the Earth temperature could benefit many insect species since they will face less severe winter months resulting in higher over-wintering survival and increase in the population sizes. Moreover, climate warming could lengthen the growing season resulting in increased growth, reproduction rate and number of generations per year (Mandrioli, 2012).

The present work predict the populations of the black parlatoria scale, $P$. ziziphi during 2035 and 2070 years compared with the pest populations of 2000, 2010 and 2012, with the respect of increasing temperature. 


\section{MATERIALS AND METHODS}

Field experiments were carried out in citrus farm located in Ismailia Governorate, Near Qussaseen Station ( Agriculture Research Center ). This study was continued for 2010 and 2012 years. The farm received normal agricultural practices and no chemical control methods were applied. The study was conducted in an area of about one feddan for citrus variety Mandarin. Fifteen trees were selected and labeled. These trees were nearly similar in size, age and vegetation. For sampling, thirty leaves were picked up at random, twice a month. The samples were put in polyethylene bags and transferred to the laboratory for inspection. These samples were examined the same day, using a stereomicroscope, for different stages of , $P$. ziziphi in Plant Protection Research Institute, Scale Insect Division lab .The data of 2000 season adopted from Helmy (2000).

Ismailia weather station were used for collecting climate data (maximum and minimum air temperatures) for 2000s,2010s and 2012s. The altitude, latitude and longitude of this weather station are $13 \mathrm{~m}, 30.6^{\circ} \mathrm{N}$ and $32.25{ }^{\circ} \mathrm{E}$, respectively. The climate change data were conducted by ClimaScope website tool to extract the projection changes in air temperature at Ismailia under the two IPCC's REP scenarios (REP4.5 and REP 8.5) that are described in Table (1). HadCM3 climate model was the base model under the two scenarios during (2041 - 2070) and (2071-2100) years according to (http://climascope.wwfus.org).

ClimaScope is a data visualization engine providing maps and data on projected climate changes for a range of global greenhouse gas emission scenarios. Outputs are stamped with metadata on which GCM was used, which carbon cycle was used, which emission scenario was used, and the source of the data in order to provide traceability. The data come from peer-reviewed models linked together within the Community Integrated Assessment System (CIAS) developed at the Tyndall Centre for Climate Change Research within the School of Environmental Sciences at the University of East Anglia. (Warren el al., 2008 ; Mitchell and Jones, 2005; Osborn,2009).

Statistical analysis was conducted, using SAS program. The $\mathrm{t}-$ test was used to find out significant differences between the Actual insect numbers in 2010 year and the estimated numbers for $(2041-2070)$ and $(2071-2100)$ years under the 0.05 level (SAS, 2000). 
Table 1. Description of IPCC Representative Concentration Pathway (RCP).

\begin{tabular}{|c|c|c|c|c|}
\hline Scenario & Radioactive forcing & $\begin{array}{c}\mathrm{CO}_{2} \text { equiv } \\
\mathrm{ppm}\end{array}$ & $\begin{array}{c}\text { Temperature } \\
{ }^{\circ} \mathrm{C}\end{array}$ & Pathway \\
\hline REP4.5 & $4.5 \mathrm{Wm}^{2}$ in 2100 & 650 & 2.4 & Stabilization without overshoot \\
\hline REP 8.5 & $8.5 \mathrm{Wm}^{2}$ in 2100 & 1370 & 4.9 & Rising \\
\hline
\end{tabular}

Representative Concentration Pathways (RCPs) are four greenhouse gas concentration (not emissions) trajectories adopted by the IPCC for its fifth Assessment Report (AR5). The pathways are used for climate modeling and research. They describe four possible climate futures, all of which are considered possible depending on how much greenhouse gases are emitted in the years to come. The four RCPs, RCP2.6, RCP4.5, RCP6, and RCP8.5, are named after a possible range of radiative forcing values in the year 2100 relative to pre-industrial values $(+2.6,+4.5,+6.0$, and $+8.5 \mathrm{~W} / \mathrm{m} 2$, respectively).

\section{RESULTS AND DISCUSSION}

Fig. (1) showed that the mean monthly temperature on Ismailia weather station in 2010 year was increased when compared to 2000 and 2012 years. In April 2000 year the mean temperature was higher than 2012. The mean temperatures were $21.6^{\circ} \mathrm{C}, 23.6^{\circ} \mathrm{C}$ and $21.1^{\circ} \mathrm{C}$ for 2000,2010 and 2012 , years respectively.

Fig. (2) presented the mean monthly temperature from Ismailia weather station in 2010 year and in 2041-2070, 2071-2100 years under RCP 4.5 climate change Scenario HadCM3 climate model. The mean temperatures were $23.6{ }^{\circ} \mathrm{C}, 24.5$ ${ }^{\circ} \mathrm{C}$ and $25.6^{\circ} \mathrm{C}$ for $2010,2041-2070$ and $2071-2100$, respectively. The mean monthly temperature for $2071-2100$ years increased $1.1^{\circ} \mathrm{C}$ than $2041-2070$ years.

Fig. (3) illustrated the mean monthly temperature form Ismailia weather station in 2041-2070 and 2071-2100 years under RCP 8.5 climate change Scenario HadCM3 climate model. The mean temperatures were $23.6^{\circ} \mathrm{C}, 24.8^{\circ} \mathrm{C}$ and $26.8^{\circ} \mathrm{C}$ for 2010, 2041-2070, 2071-2100 years, respectively. The mean monthly temperature for 2041-2070 years increased $1.2{ }^{\circ} \mathrm{C}$ than 2010 year. In addition the mean monthly temperature for $2071-2100$ years increased $3.3^{\circ} \mathrm{C}$ than 2010 year.

The obtained data in figures ( 4 and 5 ) observed the highest peaks of the black parlatoria scale, P. ziziphi occurred in mid of August and mid of July during 2000, 2010 and 2012 years for Nymphs and adults, respectively. 


\section{Relationship between mean temperature and nymph numbers of Parlatoria ziziphi:}

When the data on mean monthly temperature in (2000, 2010 and 2012 years) were regressed against the nymph numbers of $P$. ziziphi, a polynomial relationship was obtained between them. It was evident from Figures $(6,7$ and 8$)$ that the equations $(1,2$ and 3$)$.

$$
\begin{array}{ll}
Y=0.0126 x^{3}-0.7925 x^{2}+16.759 x-108.2 & \text { (eq1) for } 2000 \text { year } \\
y=0.027 x^{3}-1.8083 x^{2}+40.68 x-291.89 & \text { (eq2) for } 2010 \text { year } \\
y=0.0381 x^{3}-2.193 x^{2}+42.392 x-262.65 & \text { (eq3) for } 2012 \text { year }
\end{array}
$$

where $(y)$ was the predicted nymph numbers of $P$. ziziphi and $(X)$ was the mean temperature.

The relationship gave a good fit to the data and the co-efficient of determination were $\left(R^{2}\right)$.

$$
\begin{array}{ll}
R^{2}=0.974 & \text { for } 2000 \text { year } \\
R^{2}=0.988 & \text { for } 2010 \text { year } \\
R^{2}=0.958 & \text { for } 2012 \text { year }
\end{array}
$$

showed that the increase in nymph numbers of $P$. ziziphi occurred due to the increase in mean monthly temperature. The strongest relationship was found in 2010 year with $\mathrm{R}^{2}=0.988$.

\section{Relationship between mean temperature and adult numbers of Parlatoria ziziphi:}

When the data on mean monthly temperature in (2000, 2010 and 2012 years) were regressed against the adult numbers of $P$. ziziphi, a polynomial relationship was obtained between them. It was evident from Figure $(9,10$ and 11$)$ that the equations $y=0.0038 x^{3}-0.2161 x^{2}+4.3771 x-27.077 \quad$ (eq4) - for 2000 year $y=0.0062 x^{3}-0.4323 x^{2}+10.176 x-71.122 \quad$ (eq5) - for 2010 year $y=0.0049 x^{3}-0.2378 x^{2}+4.5388 x-27.76 \quad$ (eq6) - for 2012 year where (y) was the predicted adult numbers of $P$. ziziphi and $(X)$ was the mean temperature.

The relationship gave a good fit to the data and the co-efficient of determination
$\mathrm{R}^{2}=0.965$
for 2000 year
$\mathrm{R}^{2}=0.992$
for 2010 year
$\mathrm{R}^{2}=0.991$ for 2012 year

showed that the increase in adult numbers of Parlatoria ziziphi occurred due to the increase in mean monthly temperature. The strongest relationship was found in 2010 year with $\mathrm{R}^{2}=0.992$. 


\section{Estimated nymph numbers for Parlatoria ziziphi under two different climate change Scenario (RCP 4.5 and RCP 8.5):-}

According to (eq2) and monthly mean temperature under climate change Scenario (RCP 4.5 and RCP 8.5) for (2041 - 2070) and (2071-2100) years on Ismailia Governorate we can estimated nymph numbers for $P$. ziziphi. Table (2) showed 12.7 $\%$ increase between nymph numbers in 2010s and (2041-2070) years under RCP 4.5 scenario and $30.9 \%$. increase between 2010s and (2071-2100) years RCP 8.5 scenario had the same trend of increased between nymph numbers in 2010s and 2041-2070 years and the 2010 s and $2071-2100$ was (15.5\% and $55.3 \%$, respectively).

There were significance deference between Actual nymph numbers of $P$. ziziphi in 2010 and estimated nymph numbers in (2041 - 2070) and (2071-2100) years under RCP 4.5 and RCP 8.5 scenarios.

\section{Estimated adult numbers for Parlatoria ziziphi under two different climate change Scenario (RCP 4.5 and RCP 8.5):}

Based on (eq5) and monthly mean temperature under climate change Scenario (RCP 4.5 and RCP 8.5 ) for (2041 - 2070) and (2071-2100) years on Ismailia Governorate we can estimated adult numbers for P. ziziphi. Table (3) showed that the increased between adult numbers in 2010s and (2041-2070)s under RCP 4.5 scenario was 3.3\% and the increased between 2010 s and (2071-2100) was $11.1 \%$. RCP 8.5 scenario was same trend the increased between adult numbers in 2010 s and (2041-2070) was 5.3\% and the increased between 2010s and (2071-2100) was $21.6 \%$.There were significance deference between Actual adult numbers of $P$. ziziphi in 2010 and estimated adult numbers in (2041-2070)and ( 2071-2100) years under RCP 4.5 and RCP 8.5 scenario.

The occurrence of climate changes is evident from the increase in global average temperature, the changes in the rainfall pattern and extreme climatic events. These seasonal and long term changes would affect the fauna, flora as well as the population of insect pests. The abiotic parameters are known to have direct impact on insect population through modulation of developmental rates, survival, fecundity, voltinism and dispersal. Among the climatic factors, temperature is a key important factor (Karuppaiah and Sujayanad ,2012).

The results indicated a relationship between mean temperature and nymph numbers of $P$. ziziphi which gave a good fit to the data with co-efficient of determinations of $R^{2}=0.974,0.988$ and 0.958 for 2000,2010 and 2012 years, 
respectively. Also, the relationship between mean temperature and adult numbers of P. ziziphi gave a good fit to the data and the co-efficient of determination were $\mathrm{R}^{2}=0.965,0.992$ and 0.991 for 2000,2010 and 2012 years, respectively.

These data showed a direct proportional between the temperature and population of P. ziziphi. These findings agree with the results of Berg et. al. (2006). They stated that warm temperature halved the time required to reproduce generation time but $3^{\circ} \mathrm{C}$ rise caused 1 to 3 days increase (Spruce beetle, Dentroctonus rufipennis). Also Karuppaiah and Sujayanad (2012) showed that, declined survival rate of brown plant hopper, Nilaparvatha lugens (Stal) and rice leaf folder, Cnaphalocrocis medinalis(Guen), at higher temperature indicates that the impacts of rising temperature could do the changes in the pest population dynamics of rice ecosystem.

Our data also estimated nymph numbers for $P$. ziziphi under two different climate change Scenario (RCP 4.5 and RCP 8.5). The results indicated that an average yearly increased between nymph numbers in 2010s \& (2041-2070) and in 2010s and (2071-2100) under RCP 4.5 , were $12.7 \%$ and 30.9\%, respectively. While under RCP 8.5 they were $17.5 \%$ and $55.3 \%$, respectively . Estimated adult numbers for $P$. ziziphi under two different climate change Scenario (RCP 4.5 and RCP 8.5).

The results showed that the an average yearly increase between adult numbers in 2010s \& (2041-2070) and in 2010s and (2071-2100) under RCP 4.5, were $3.3 \%$ and $11.1 \%$, respectively. While under RCP 8.5 were $5.3 \%$ and $21.6 \%$, respectively . The same trend studied by Kocmankova et. al. (2011). They suggested the likely widening of the pests habitats and an increased in the number of generations per year. According to the HadCM- high scenario, the area of arable land affected by a third generation per season of Colorado potato beetle in 2050 is $45 \%$ higher, and by a second generation of the European corn borer is nearly $61 \%$ higher, compared to present levels. The our results indicated that the population of $P$. ziziphi in (2041-2070) and (2071-2100) years will increased. Here It is recommended that to produce biochemical and natural enemies tolerant to high temperature to control this pest is very important in order to help the researchers, growers and extensions controlling this pest in the future. This recommendation will to solve the problem of increasing this pest in the future in Egypt. 


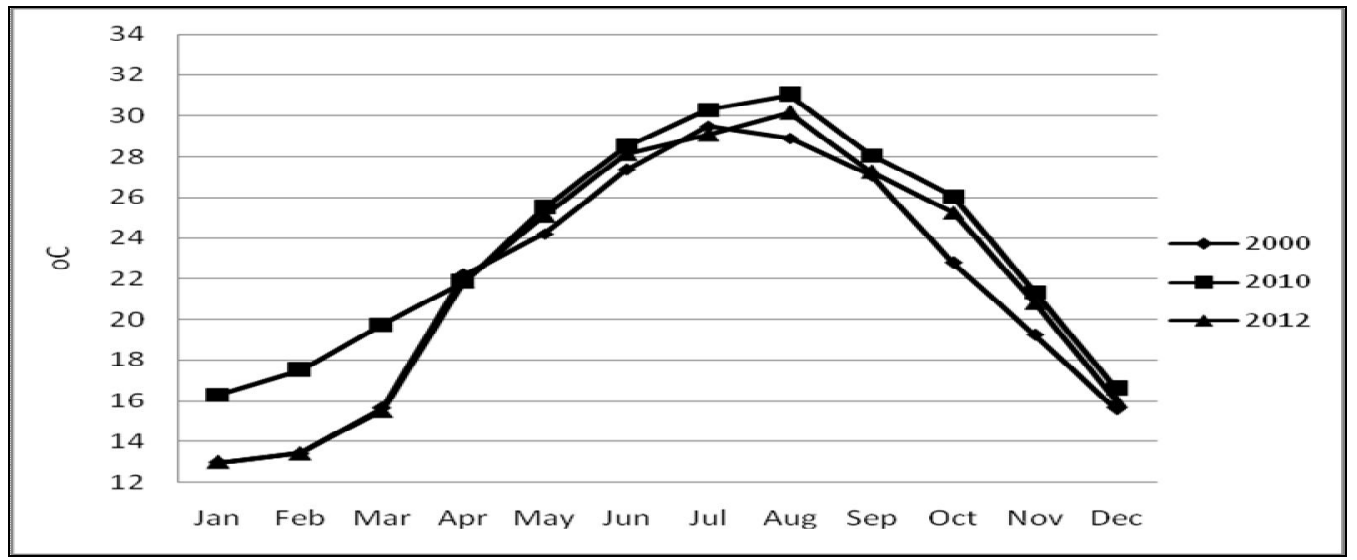

Fig. 1. Mean temperature on Ismailia weather station in 2000, 2010 and 2012 years.

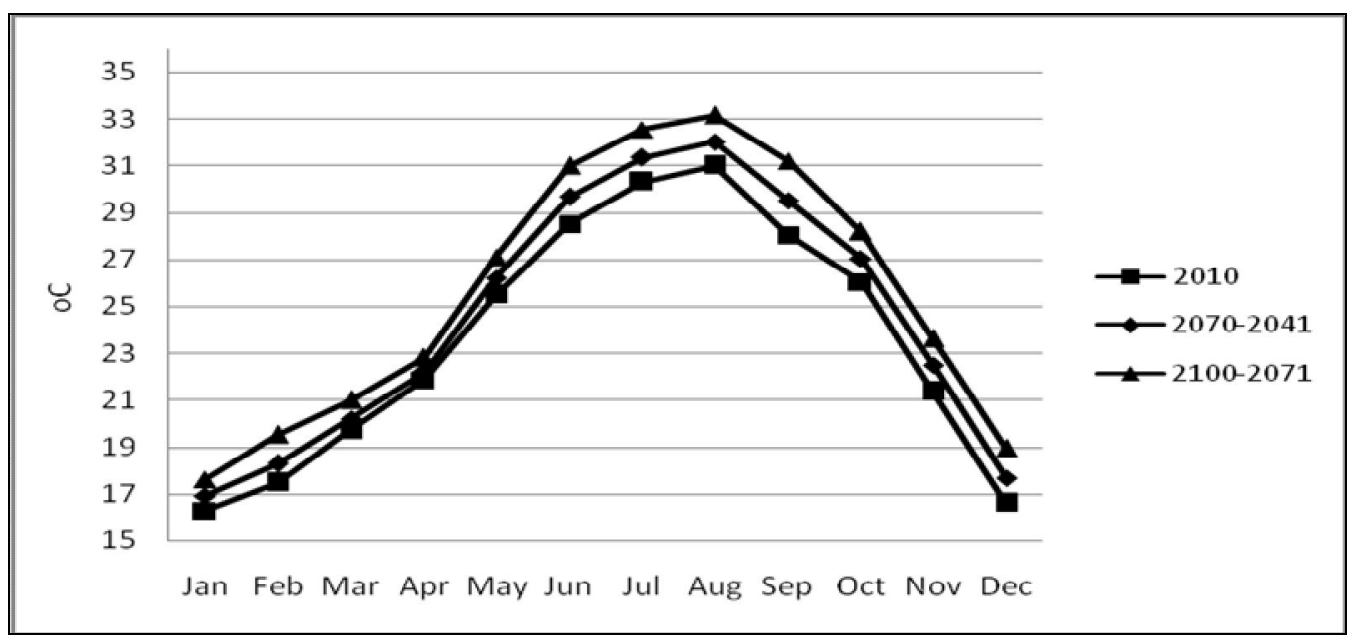

Fig. 2. Mean temperature on Ismailia weather station in 2010 year and (20412070),(2071-2100) under RCP 4.5 Scenario.

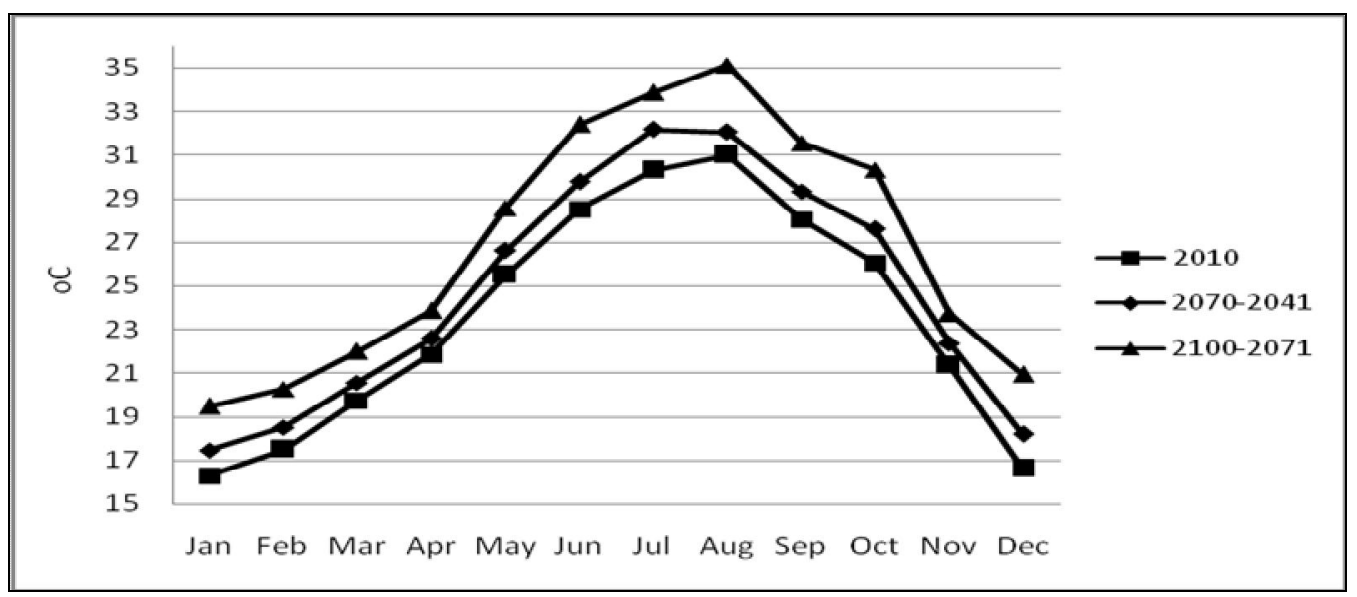

Fig. 3. Mean temperature on Ismailia weather station in 2010 year and (2041-2070), (2071-2100)years under 8.5 Scenario. 


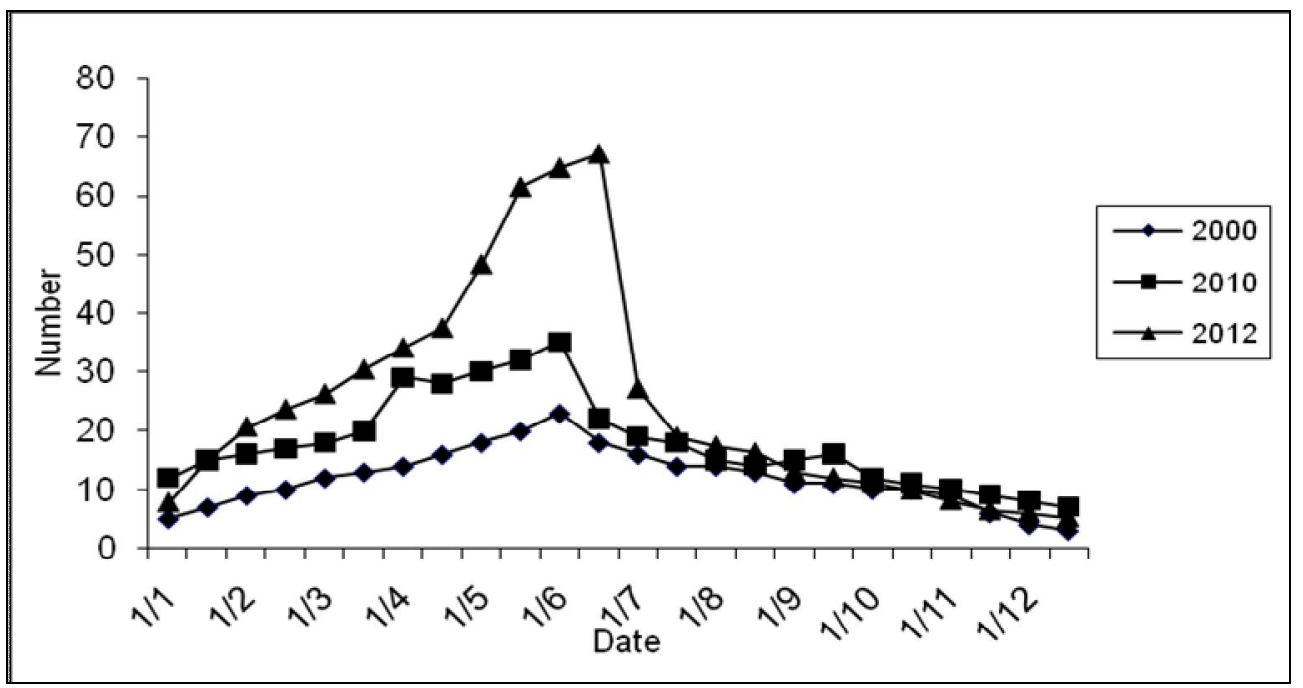

Fig. 4. Nymph numbers of Parlatoria ziziphi in 2000,2010 and 2012 years

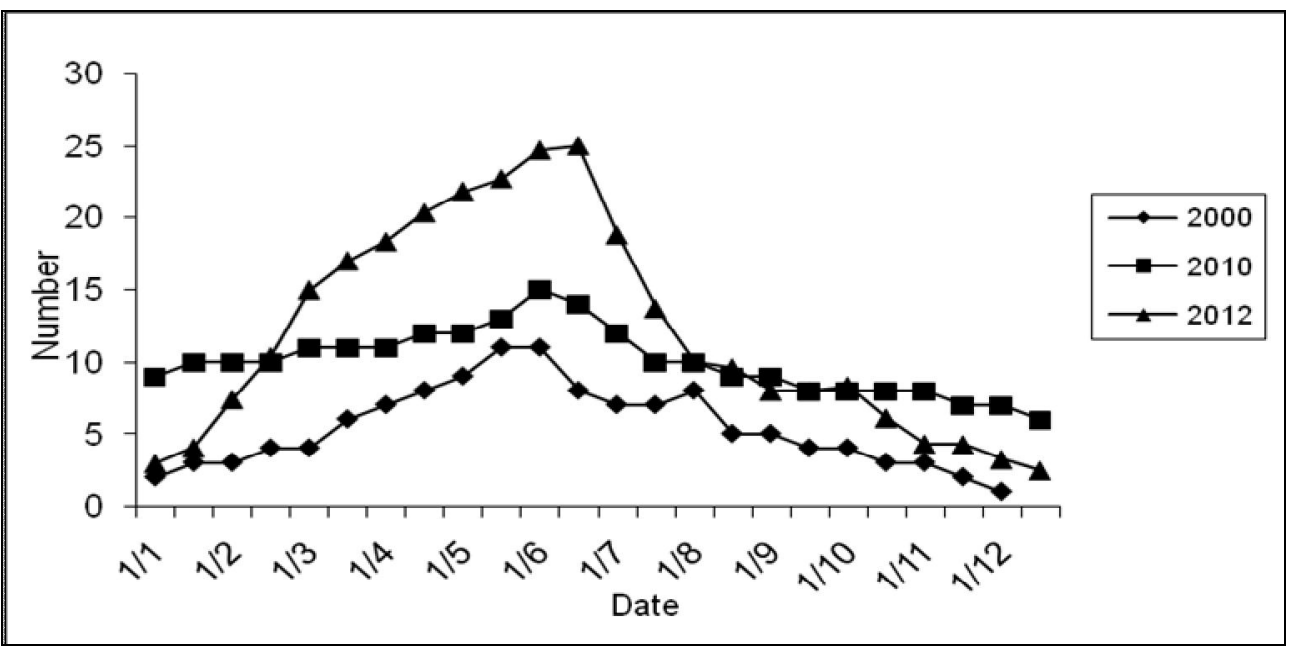

Fig. 5. Adult numbers of Parlatoria ziziphi in 2000, 2010 and 2012 years. 


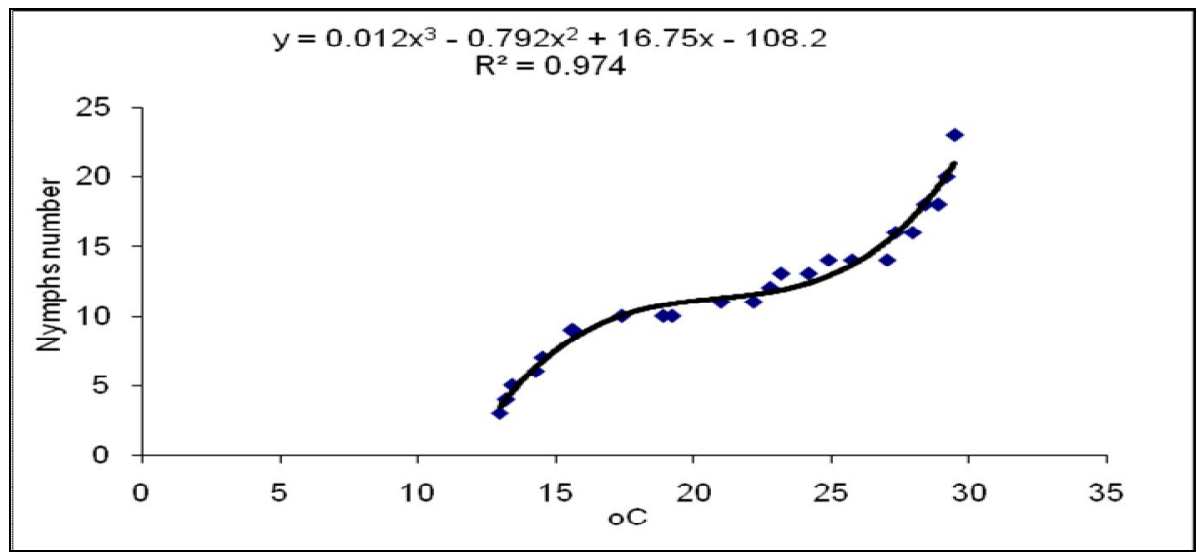

Fig. 6. Relationship between mean temperature in 2000 year and nymph numbers of Parlatoria ziziphi.

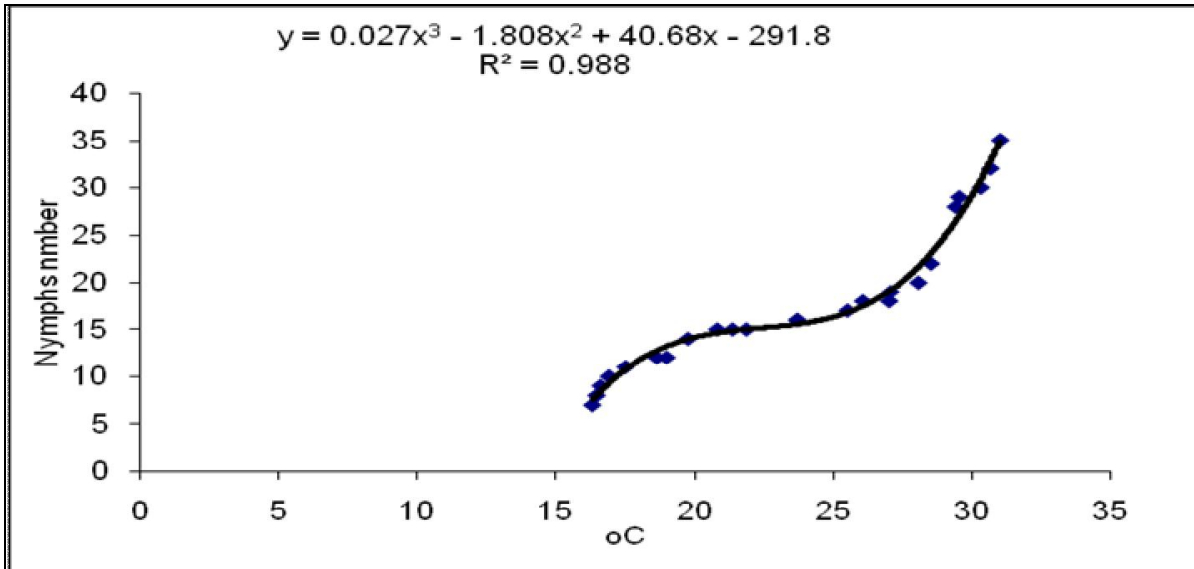

Fig. 7. Relationship between mean temperature in 2010 year and nymph numbers of Parlatoria ziziphi.

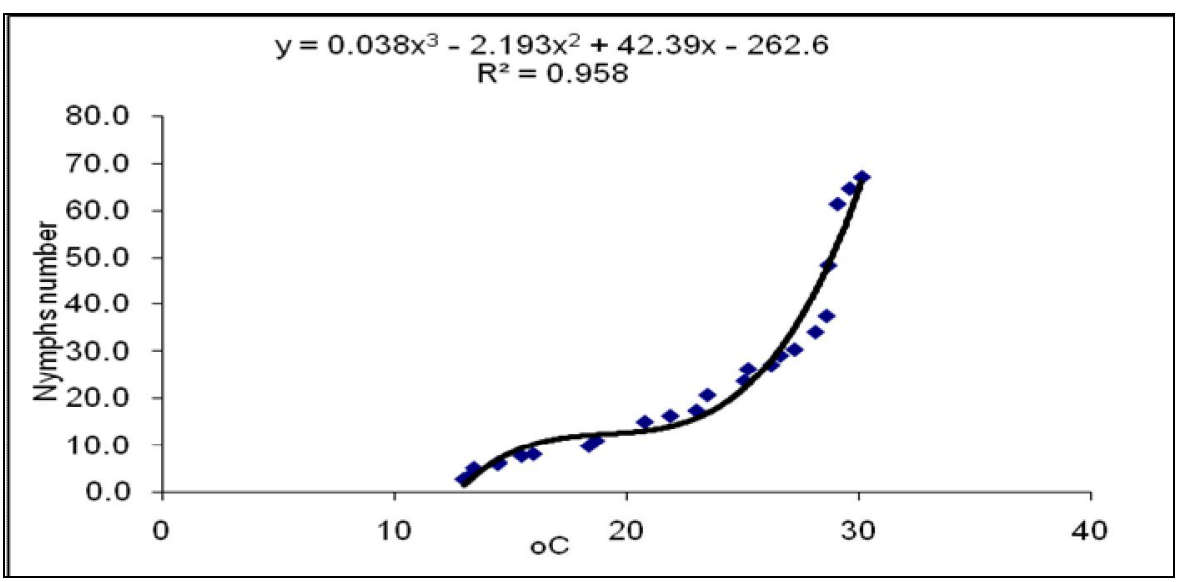

Fig. 8. Relationship between mean temperature in 2012 year and nymph numbers of Parlatoria ziziphi. 


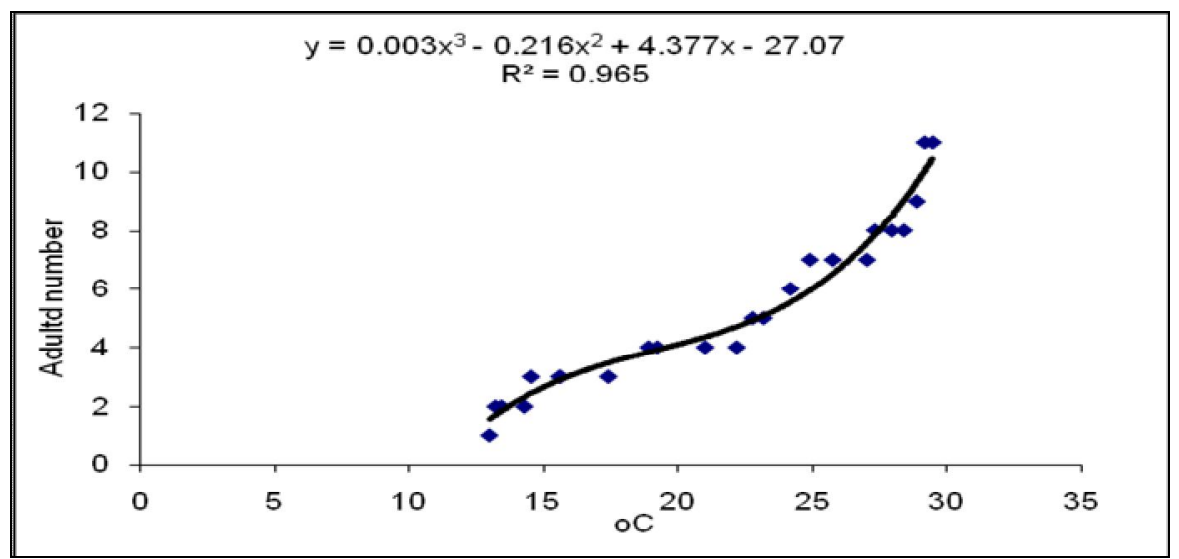

Fig. 9. Relationship between mean temperature in 2000 year and adult numbers of Parlatoria ziziphi.

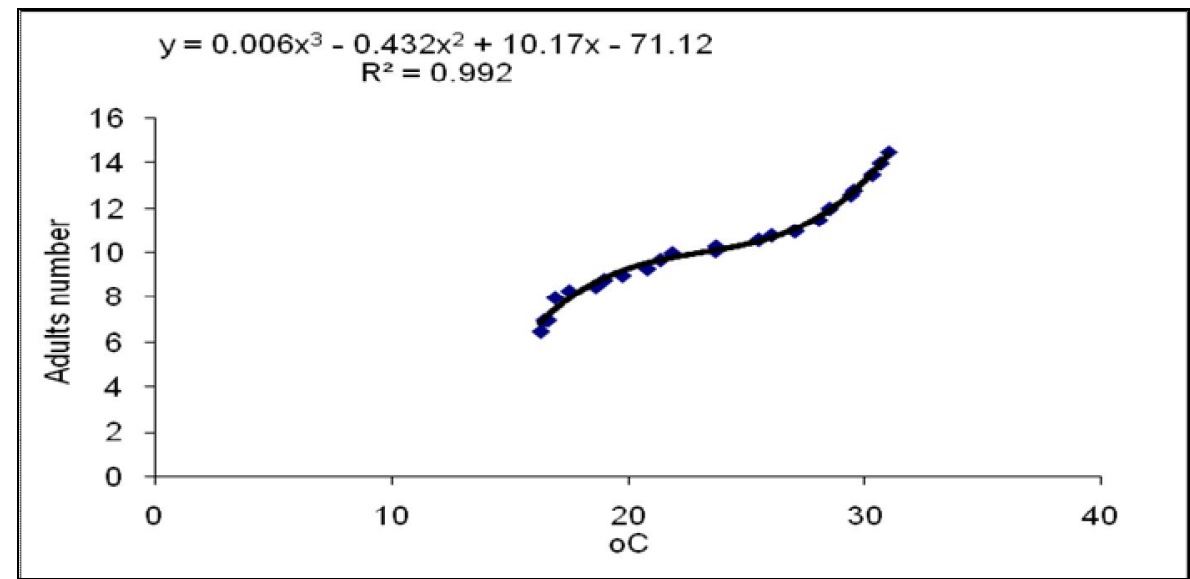

Fig. 10. Relationship between mean temperature in 2010 year and adult numbers of Parlatoria ziziphi.

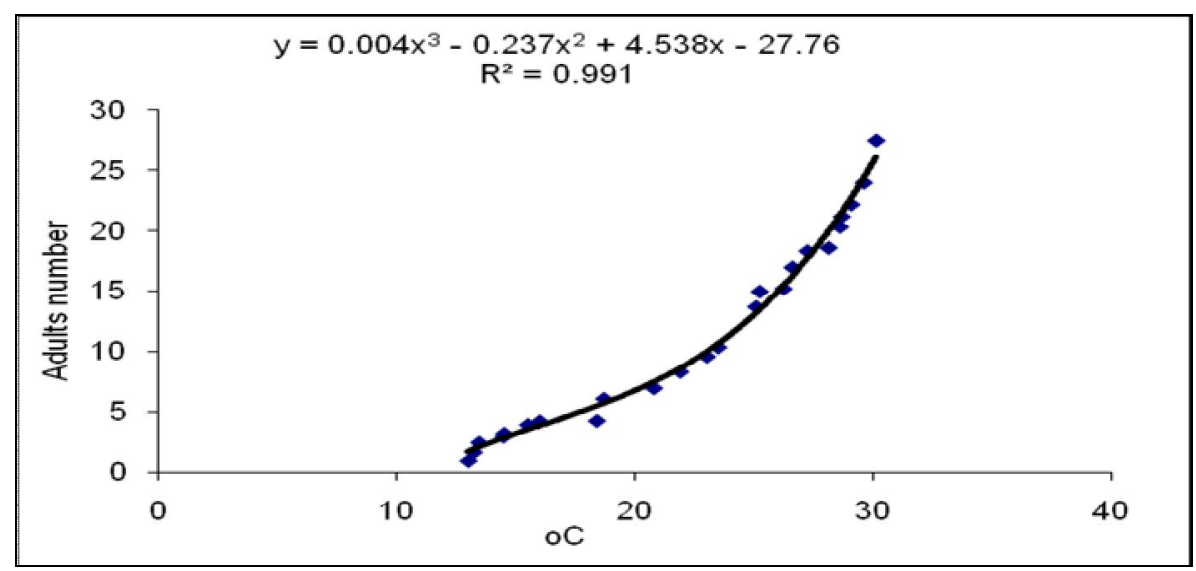

Fig. 11. Relationship between mean temperature in 2012 year and adult numbers of Parlatoria ziziphi. 
Table 2. Nymph numbers of Parlatoria ziziphi in 2010 year and (2041-2070), (20712100) years under two different climate change Scenario RCP 4.5 and RCP 8.5 .

\begin{tabular}{|c|c|c|c|c|c|c|}
\hline & \multirow[b]{2}{*}{ Month } & \multirow{2}{*}{$\frac{\text { Real data }}{2010}$} & \multicolumn{2}{|c|}{ RCP 4.5} & \multicolumn{2}{|c|}{ RCP 8.5} \\
\hline \multirow{13}{*}{$\begin{array}{l}\text { Nymphs } \\
\text { number }\end{array}$} & & & $\begin{array}{c}2041- \\
2070 \\
\end{array}$ & $\begin{array}{l}2071- \\
2100\end{array}$ & 2041-2070 & 2071-2100 \\
\hline & Jan & 8 & 9.5 & 11.2 & 10.8 & 14.0 \\
\hline & Feb & 12 & 12.4 & 14.0 & 12.8 & 14.6 \\
\hline & Mar & 14 & 14.5 & 15.0 & 14.8 & 15.3 \\
\hline & Apr & 15 & 15.4 & 15.6 & 15.5 & 16.0 \\
\hline & May & 17 & 18.3 & 19.9 & 18.9 & 24.0 \\
\hline & Jun & 28 & 28.4 & 35.6 & 28.9 & 46.2 \\
\hline & Jul & 30 & 38.0 & 47.3 & 44.3 & 60.6 \\
\hline & Aug & 35 & 43.0 & 53.2 & 43.2 & 76.0 \\
\hline & Sep & 20 & 27.7 & 37.0 & 26.9 & 39.4 \\
\hline & Oct & 18 & 19.8 & 22.7 & 21.0 & 31.8 \\
\hline & Nov & 15 & 15.5 & 15.9 & 15.5 & 16.0 \\
\hline & Dec & 10 & 11.3 & 13.4 & 12.3 & 14.9 \\
\hline \multicolumn{2}{|c|}{ Mean } & 18.5 & 21.2 & 25.1 & 22.1 & 30.7 \\
\hline \multicolumn{3}{|c|}{$P$ value } & $*$ & $*$ & $*$ & $*$ \\
\hline \multicolumn{3}{|c|}{ Increase } & $12.7 \%$ & $30.9 \%$ & $17.5 \%$ & $55.3 \%$ \\
\hline
\end{tabular}

*significant level 0.05

Table 3. Adult numbers of Parlatoria ziziphi in 2010 year and (2041-2070), (20712100) years under two different climate change Scenario RCP 4.5 and RCP 8.5

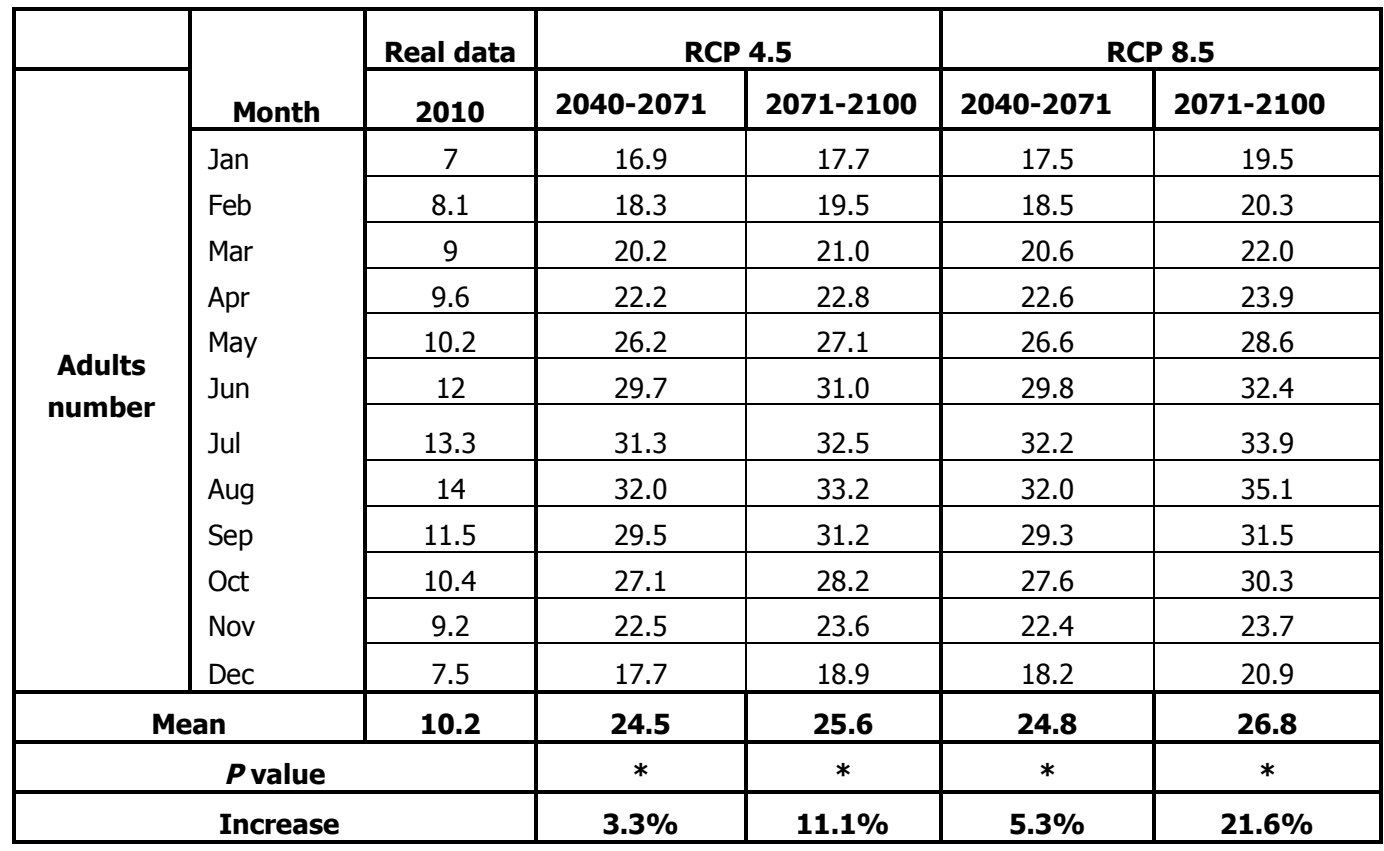

*significant level 0.05 


\section{REFERENCES}

1. Berg, E.E., J.D. Henry, C.L. Fastie, A.D. De Volder and S.M. Matsuoka, 2006. Spruce beetle outbreaks on the Kenai Peninsula, Alaska and Kluane National Park and Reserve, Yukon Territory: Relationship to summer temperatures and regional differences in disturbance regimes. Forest Ecol. and Mgt., 227(3): 219232.

2. CABI. 2007. Crop Protection Compendium. Parlatoria ziziphi (Lucas, 1853), black parlatoria scale. Available from:

http://www.cabicompendium.org/cpc/datasheet.asp?CCODE=PARLZI\&COUNTRY $=0$ as last updated on 25 April 2006 (accessed on 30 April 2008).

3. Coll, M. and Abd-Rabou, S. 1998. Effect of oil emulsion sprays on parasitoids of the black parlatoria, Parlatoria ziziphi, in grapefruit. Biocontrol, 43: 29-37.

4. El-Bolok, M.M.; Sweilem, S.M. and Abdel Aleem, R.Y. 1985. Seasonal variation in the population of Parlatoria zizyphus (Lucas) at Giza region. Bull. Soc. Entomol., Egypt., 65:281-288.

5. Ghabbour, M.W. and Mohammad, Z.K. 1996. The Diaspididae of Egypt (Coccoidea: Homoptera). J. Egypt. Ger. Soc. Zool. 21(E): 337-369.

6. Hassan, N. A.; Radwan, S. G. and El-Sahn, O. M.N. (2012): Common scale insects (Hemiptera:Coccoidea) in Egypt. Egypt. Acad. J. Biol. Sci., 5(3): 153 -160.

7. Helmy, S.M.Y. 2000. Ecological studies on the black parlatoria scale, Parlatoria ziziphus (Lucas) (Homoptera : Diaspididae) and its natural enemies in Egypt. M.Sc. Thesis, Faci Agric., Cairo Univ., Egypt. 146 pp.

8. Intergovernmental Panel on Climate Change (IPCC). 2013. Impacts, Adaptation and Vulnerability. THE PHYSICAL SCIENCE BASIS . Contribution of Working Group I- TWELFTH SESSION- to the Fifth Assessment Report of the Intergovernmental Panel on Climate Change, pp. 15-29

9. Kocmankova, E.,Trnka, M., Eitzinger, J., Dubrovsky, M., P. Stepanek; Semeradova, D., Balek, J., Skalak, P., Farda, A., Juroch, J. and Zalud, Z. 2011. Estimating the impact of climate change on the occurrence of selected pests at a high spatial resolution: a novel approach. J. Agric. Sci., 149 ( 2): 185-195.

10. Karuppaiah, V.and G.K. Sujayanad. 2012. Impact of Climate Change on Population Dynamics of Insect Pests. World J. Agric. Sci. 8 (3): 240-246

11. Mandrioli, M. 2012. Someone like it hot? Effects of global warming on insect immunity and microbiota , IS] 9: 58-63 
12. Mitchell, T.D., Jones, P.D., 2005. An improved method of constructing a database of monthly climate observations and associated high-resolution grids. International Journal of Climatology 25: 693-712

13. Osborn, T.J. 2009. A user guide for ClimGen: a flexible tool for generating monthly climate data sets and scenarios. Climatic Research Unit, University of East Anglia, Norwich, 17pp.

14. Salama, H.S.; Abdel Salam, A.L., Donia, A. and Negahed, M.I. 1985. Studies on the population and distribution pattern of Parlatoria zizyphus (Lucas) in citrus orchards in Egypt. Insect. Sci. Appl., 6(1):43-47.

15. SAS. 2000. Statistical Analysis System, SASUser's Guide: Statistics. SAS Institute Inc. Editors, Cary, NC.

16. Serag, S.A. 1997. Studies on biological control of some piercing and sucking insects. M.Sc. Thesis, Fac. Agric., Al-Azhar Univ., Egypt, 136pp.

17. Sweilem, S.M.; El-Bolok, M.M. and Abdel-Aleem R.Y. 1985. Effect of different levels of trees, different cardinal directions tree core and leaf surface on the distribution of Parlatoria zizyphus (Lucas) in correlation with the year seasons. Bull. Soc. Entomol. Egypte., 65:289-299.

18. Ulenberg, S.A. 2012. Arthropods of Economic Importance - Diaspididae of the World.

http://wbd.etibioinformatics.nl/bis/diaspididae.php?menuentry=soorten\&selected $=$ beschrijving\&id $=162$

19. Warren, R. de la Nava Santos, S., Ford, R., Osborn, T.J., Raper, S, et. al. 2008. Development of the Community Integrated Assessment System (CIAS), a multiinstitutional modular integrated assessment approach for modelling climate change, and of SoftIAM, its supporting software. Environmental Modelling and Software 23: 592-610. 


\title{
تقدير تعداد حشرة البارلاتوريا القشرية السوداء بأستخدام سيناريوهات
}

\section{RCP}

\author{
شعبان عبدربه' أحمد عونى أحمد فرج" \\ ا ـ ـ معه بحوث وقاية النباتات- مركز البحوث الزراعية - الدقى - جيزة

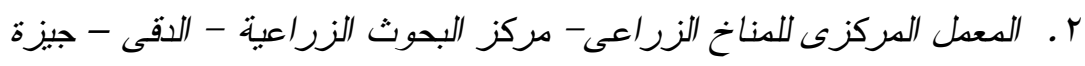

حشرة البارلاتوريا القشرية السوداء من الآفات الهامة التى تصيب الموالح فى مصر .

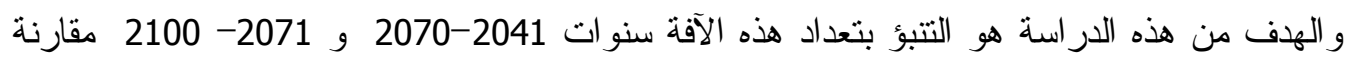

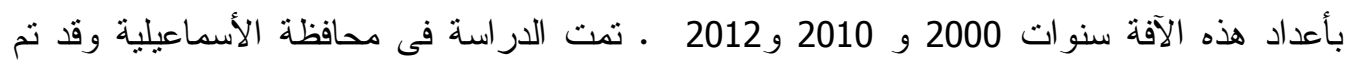
أستخدام نتائج محطة الأرصاد فى محافظة الأسماعيلية لأخذ درجات الحرارة اللازمة للار اسة و و تم ايضا استخدام سيناريو هات ( RCP 4.5 و 8.5 RCP) . و وأن نموذج المناخ المستخدم للسيناريوهات المستخدمة كان Had CM3 وقد بينت النتائج أن العلاقة بين متوسط درجات الحرارة وأعداد

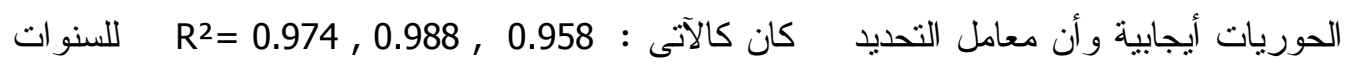

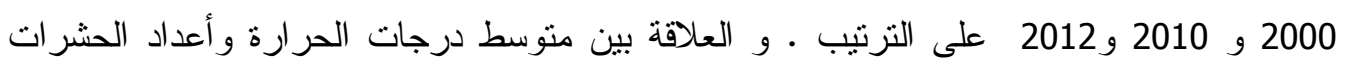

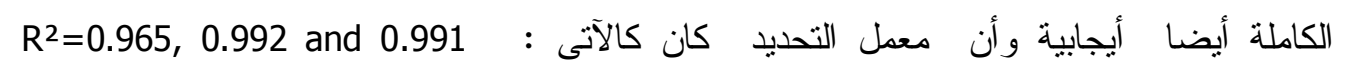

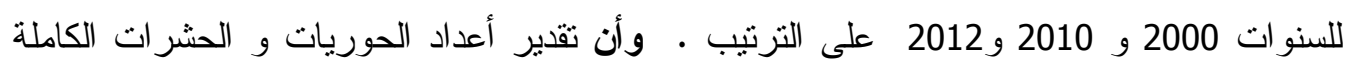

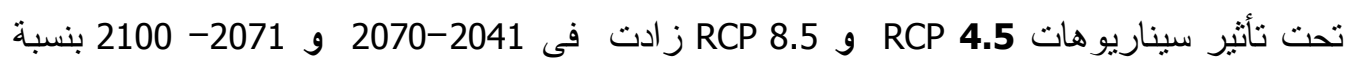

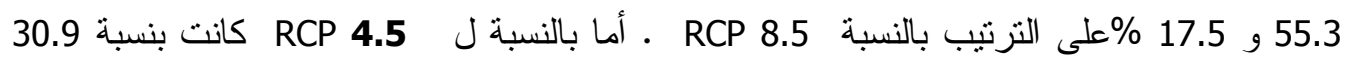

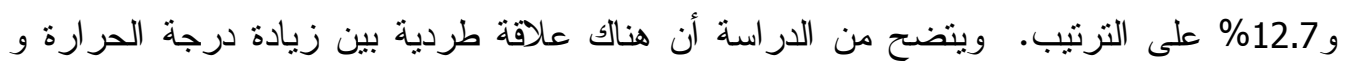

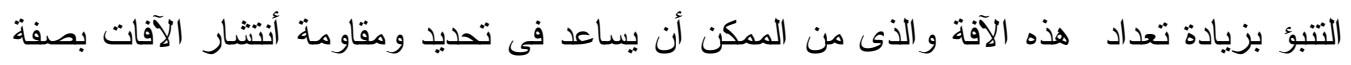

